\title{
International Journal of Diabetes in Developing Countries
}

\author{
Hemraj B. Chandalia
}

Received: 26 December 2012 / Accepted: 27 December 2012 / Published online: 27 January 2013

(C) Research Society for Study of Diabetes in India 2013

The journal is entering its $33 \mathrm{rd}$ eventful year of publication. It is right time to recount the history of this journal, its transformation into a truly international journal and the reasons to stake its rightful claim amongst the diabetology journals. There is also a personal reason for me to undertake this writing as I lay down the office of the Editor-in-Chief after my participation in the editorial process of this journal for the past 22 years.

Origin and Early years (1981-1990)

The journal was started under the name "Diabetes Bulletin" by late Prof. M.M.S. Ahuja, Professor of Medicine at the All India Institute of Medical Sciences, Delhi. Prof. Ahuja's effort was commendable, as there were not many established medical journals published at that point of time from India. It was meant to be a quarterly journal, it carried an occasional original article and reported a few reviews and abstracts of articles published elsewhere. As the access to literature was limited in those days, the publication of abstracts of current articles was an important function, serving need of the medical and research community. Publication of the journal was an uphill task. Hence, Prof. M.M.S. Ahuja enlisted help of Prof. H. B. Chandalia, Honorary Professor of Medicine, Grant Medical College, Mumbai. The journal's name was re-christened from Diabetes Bulletin to International Journal of Diabetes in Developing Countries, in consonance with the expanding vision of the new editors. International Journal of Diabetes in Developing Countries grew steadily due to excellent selfless academic environment created by the founding fathers and executive patrons of the Research Society for the Study of Diabetes in

\section{H. B. Chandalia $(\bowtie)$}

Founding Editor, International Journal of Diabetes in Developing Countries, Diabetes Endocrine Nutrition Management \& Research Centre, Mumbai, Maharshtra, India

e-mail: ijddcjournal@gmail.com
India: Prof. M.M.S. Ahuja, Prof. B. B. Tripathy, Prof. O. P. Gupta and in addition, Prof Sam Moses, Prof. H. B. Chandalia, Prof. C. Munichoodappa, Prof. Binode Kumar Sahay and Prof. A. K. Das. The editorial journal of the office was shifted to Mumbai from 1991 onwards; Prof Ahuja and Prof Chandalia continued to edit it, till the demise of Prof. Ahuja in 1998. Thereafter, Prof. H. B. Chandalia continued to be the Editor-in-Chief, till December 2012, when the baton has been passed on to Dr. G. R. Sridhar, of Visakhapatnam. Currently the back office continues to be in Mumbai for logistic reasons to consolidate the editorial process further.

\section{Editorial Process}

The current editorial process is a well-set, seamless operation, maintaining standard of ethics and probity in scientific publications (Table 1).

Most contributions are sent to a set of three reviewers, identified by literature search. The editors decisions are almost totally based on peer review, except in a few conflicting situations. If the article is accepted, the authors are requested to revise the article as per the comments of the reviewer. After revision, reviewer is again asked to see if the article has been suitably modified. Thus, the whole process maintains confidentiality and dignity of authors as well as reviewers. In the year 2012, the journal used services of 113 reviewers. The rejection in the years 2010-2012 was 31.17 to $46.15 \%$. The article submission rate is rising steadily. In the year 2012, (till December 15) 247 articles were submitted for publication.

The Editor-in-Chief is a member of the International Committee of Medical Journal Editors (ICMJE); an organization enforcing high ethical standards for the editors.

The time-duration from the acceptance of the article to its publication, in the years 2011 and 2012, was 30 days. 
Table 1 Data showing functioning of the Int J Diab Dev Ctries for the past 3 years

\begin{tabular}{llll}
\hline STATUS & 2010 & 2011 & 2012 \\
\hline Total no. of Manuscripts Submitted & 222 & 234 & 247 \\
Acceptance Rate & $9.91 \%$ & $14.53 \%$ & $14.98 \%$ \\
Rejection Rate & $35.14 \%$ & $46.15 \%$ & $31.17 \%$ \\
Revisions requested & 25 & 62 & 241 \\
Average Time from Submission to First Decision (in days) & 87.8 & 110.2 & 97.9 \\
Average Time for Peer Review (in days) & 22.1 & 22.9 & 19.4 \\
\hline
\end{tabular}

\section{Publication process, circulation and accessibility}

The publication of the journal was done by RSSDI directly till the year 2005. In 2006 it was passed on to Medknow for a period of 5 years. Springer India is the publisher from 2011 for a period of 5 years. The access to the journal was open during its publication by Medknow; hence, it was possible to lodge it with Pubmed Central without any preview by the abstracting agency for a year. Presently, the journal has dual accessibility; the subscribers can view it through the Springer-link while open access to full length articles continues at RSSDI website www.rssdi.in.

The publication schedule of the journal is regular. Almost 5600 RSSDI members receive the journal free, while there are 2088 paid online subscribers from other countries.

\section{Quality of articles and author base}

The quality of articles received by the journal and ultimately accepted for publication is steadily improving. Most articles $(>90 \%)$ are original research papers. A few selected Editorials and review articles are commissioned by the journal, the majority being submitted are uncomissioned articles; which makes the process highly competitive and maintains the quality.

The journal has very wide author-base. For example, in the years 2011 and 2012 articles from 32 and 38 countries were received for publication. The journal is developing into a powerful mouthpiece of South-Asia region and Middle East. In fact, it fills up a great void in this regard, as there is no established diabetology journal from this area.

The articles published cover niche areas in diabetology, which is unique to this journal. For example, in the year 2008-2012, 17 articles on the indigenous and herbal antidiabetic drugs appeared in the journal [1-17]. These articles were on well-planned animal experiments or randomized, double-blind control studies in humans. In the same period, 23 articles pertaining to epidemiology of diabetes and its complications, which is unique for the region were published [18-41].

\section{Abstracting, indexing and impact factor}

The development of a journal is closely dependent on its visibility. Hence, abstracting and indexing agencies have an important role in this regard. International Journal of Diabetes in Developing Countries found its way in a large number of these agencies in the year 2006 onwards, during its publication by Medknow. This continues to grow; currently most important agencies abstracting and indexing are:

- Science Citation Index Expanded

- Global Health CAB International

- Academic Search

- CAB Abstracts

- Health Reference Center Academic

Fig. 1 Impact Factor Trend

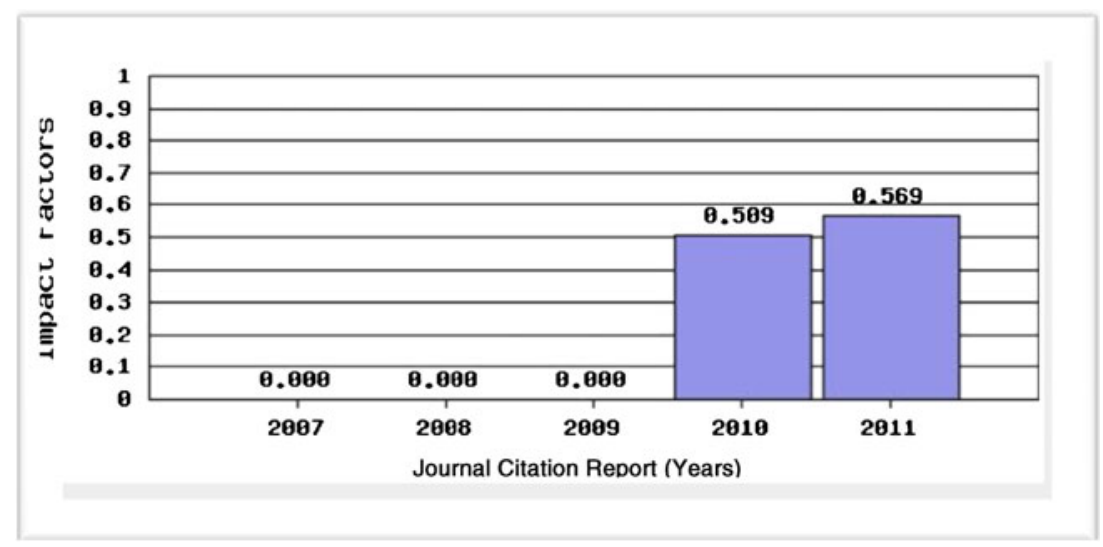




\section{- IBIDS}

- SCOPUS

- Google Scholar

- EBSCO

- Current Abstracts,

- Expanded Academic

- Index Copernicus

- Journal Citation Reports/Science Edition

- OCLC

- SCImago

- Summon by Serial Solutions

The impact factor of the journal (Fig. 1) is 0.569. It started rising in the year 2009 and has marginally increased in the year 2011.

It is expected to grow rapidly in the next few years.

\section{Future of International Journal of Diabetes in Developing Countries}

The journal is an official publication of Research Society for the Studies of Diabetes in India, which is a vigorously working, powerful academic body in India. As India is hub of diabetes literature and science, this journal has a great promise in future. Each quarterly issue now carries more articles and it may be possible in future to convert it into 6 or 12 issues a year. The quality of articles will improve with increasing submissions and higher rejection rate. Its avowed policy is to continue full and free access. Future of this journal is indeed highly promising.

\section{References}

1. International Journal of Diabetes in Developing Countries. Accessed 20/Dec/2012. url: http://rssdi.in/new/

2. Jain R, Kabadi U, Kabadi M. Hypoglycemic activity of Hemidesmus indicus R. Br. on streptozotocin-induced diabetic rats. Int J Diab Dev Ctries. 2008;28:6-10.

3. Najmi A, Mohammad N, Khan RA, Haque SF. Effect of Nigella sativa oil on various clinical and biochemical parameters of insulin resistance syndrome. Int J Diab Dev Ctries. 2008;28:11-4.

4. Andallu B, Kumar AVV, Varadacharyulu NC. Lipid abnormalities in streptozotocin-diabetes: Amelioration by Morus indica L. cv Suguna leaves. Int J Diab Dev Ctries. 2009;29:123-8.

5. Gupta RN, Pareek A, Suthar M, Rathore GS, Basniwal PK, Jain D. Study of glucose uptake activity of Helicteres isora Linn. Fruits in L-6 cell lines. Int J Diab Dev Ctries. 2009;29:170-3.

6. Thakkar NV, Patel JA. Pharmacological evaluation of "Glyoherb": A polyherbal formulation on streptozotocin-induced diabetic rats. Int J Diab Dev Ctries. 2010;30:1-7.

7. Adiga S, Bairy KL, Meharban A, Punita ISR. Hypoglycemic effect of aqueous extract of Trichosanthes dioica in normal and diabetic rats. Int J Diab Dev Ctries. 2010;30:38-42.
8. Hypoglycemic effect of aqueous extract of Trichosanthes dioica in normal and diabetic rats. Int J Diab Dev Ctries. 2010; 30: 38-42.

9. Jayakuamar RV. Herbal Medicines for type-2 diabetes. Int J Diab Dev Ctries. 2010;30:111-2.

10. Ezeigbo II. Anti-diabetic potential of methanolic leaf extracts of Icacina trichantha in alloxan-induced diabetic mice. Int J Diab Dev Ctries. 2010;30:150-2.

11. Kumar N, Gupta AK, Prakash D, Kumar P. Hypoglycemic activity of Onosma hispidum (Ratanjot). Int J Diab Dev Ctries. 2010;30:213-6.

12. Ukwe CV, Ubaka CM. Hypoglycemic activity of leaves of Acanthus montanus T. Anderson (Acanthaceae) in rats. Int J Diab Dev Ctries. 2011;31:32-6.

13. Ramudu SK, Mallikarjuna K, Kesireddy SR. Efficacy of ethanolic extract of ginger on kidney lipid metabolic profiles in diabetic rats. Int J Diab Dev Ctries. 2011;31:97-103.

14. Pramanath R, Lakshmidevi N, Jayashree K, Suresh RN. Evaluation of anti-diabetic effect of Trigonella foenum graecum Linn. Leaf extract streptozotocin-induced diabetic rats. Int J Diab Dev Ctries. 2012;32:164-9.

15. Renjith RS, Rajamohan T. Young influorescence of Cocos nucifera contributes to improvement of glucose homeostasis and antioxidant status in diabetic rats. Int J Diab Dev Ctries. 2012;32:193-8.

16. Bhaskar A, Vidhya VG. Hypoglycemic and hypolipidemic activity of Hibiscus rosa sinensis Linn on streptozotocin-induced diabetic rats. Int J Diab Dev Ctries. 2012;32:214-8.

17. Arun KP, Murugan R, Kanna RM, Rajalakshmi S, Kalaiselvi R, Komathi V. The impact of Pharmaceutical care on the clinical outcome of diabetes mellitus among a rural patient population. Int J Diab Dev Ctries. 2008;28:15-8.

18. Gooneratne IK, Ranaweera AKP, Liyanarachchi NP, Gunawardane N, Lanerolle RD. Epidemiology of chronic kidney disease in a Sri Lankan population. Int J Diab Dev Ctries. 2008;28:60-4.

19. Khatib NM, Quazi ZS, Gaidhane AM, Waghmare TS, Goyal RC. Risk factors of type-2 diabetes mellitus in rural Wardhan: A community based study. Int J Diab Dev Ctries. 2008;28:7982.

20. Tiwari RR, Deb PK, Debbarma A, Chaudhuri R, Chakraborti A, Lepcha M, Chakraborti G. Risk factor analysis in self-reported diabetes in a rural Kerala population. Int J Diab Dev Ctries. 2008;28:91-4.

21. Sharifi N, Khoshbaten M, Aliasgarzade A, Bahrami A. Celiac disease in patients with type 1 diabetes mellitus screened by tissue transglutaminase antibodies in northwest of Iran. Int J Diab Dev Ctries. 2008;28:95-9.

22. Azevedo M, Alla S. Diabetes in Sub-Saharan Africa: Kenya, Mali, Mozambique, Nigeria, South Africa and Zambia. Int J Diab Dev Ctries. 2008;28:101-8.

23. Purti AJ, Vedapriya DR, Bazroy J, Gupta S, Cherian J, Vishwanathan M. Prevalence of diagnosed diabetes in an urban area of Puducherry, India: Time of preventive action. Int J Diab Dev Ctries. 2009;29:1-5.

24. Avasarala KA, Bachu A. Survey of childhood diabetes and impact of school level educational interventions in rural schools in Karimnagar district. Int J Diab Dev Ctries. 2009;29:69-73.

25. Venkatraman K, Kannan AT, Mohan V. Challenges in diabetes management with particular reference to India. Int $\mathrm{J}$ Diab Dev Ctries. 2009;29:103-9.

26. Shah VN, Kamdar PK, Shah N. Assessing the knowledge, attitudes and practice of type 2 diabetes among patients of Saurashtra region. Gujarat Int J Diab Dev Ctries. 2009;29:118-22.

27. Rai M, Kishor J. Myths about diabetes and its treatment in North Indian population. Int J Diab Dev Ctries. 2009;29:129-32.

28. Muninarayana C, Balachandra G, Hiremath SG, Iyengar K, Anil NS. Prevalence and awareness regarding diabetes mellitus in rural Tamaka. Kolar Int J Diab Dev Ctries. 2010;30:18-21. 
29. Rao CR, Kamath VG, Shetty A, Kamath A. A study on the prevalence of type 2 diabetes in coastal Karnataka. Int J Diab Dev Ctries. 2010;30:80-5.

30. Mohamud WNW, Suraiami M. Prevalence of diabetes, impaired fasting glucose and metabolic syndrome among female Orang Asli community in Peninsular Malaysia. Int J Diab Dev Ctries. 2010;30:118-22.

31. Mohan V, Deepa M. Prevalence of diabetes and metabolic syndrome among Asians. Int J Diab Dev Ctries. 2010;30:173-5.

32. Chakraborti R, Dey S, DKhar PS, Thabah CR, Rynjah W. Diabetics of Northeast India are at risk of dietary Zinc and Manganese deficiency: Possible improvement through consumption of some traditional edibles or edibles of limited popularity. Int J Diab Dev Ctries. 2010;30:201-7.

33. Sharma R, Grover VL, Chaturvedi S. Recipe for diabetes disaster: a study of dietary behaviors among adolescent students in South Delhi. India Int J Diab Dev Ctries. 2011;31:4-8.

34. Chandalia HB. Will the epidemic of diabetes in India subside? Int J Diab Dev Ctries. 2011;31:45-7.

35. Vuvor F, Steiner-Aseidu M, Armar-Klemesu M, Armah S. Population-based study of diabetic mellitus prevalence and its associated factors in adult Ghanaians in the greater Accra region. Int J Diab Dev Ctries. 2011;31:149-53.
36. Al-Shafaee MA, Bhargava K, Al-Farsi YM, Mcilvenny S, AlMandhari A, Al-Adawi S, Manari AA. Prevalence of prediabetes and associated risk factors in an adult Omani population. Int J Diab Dev Ctries. 2011;31:161-5.

37. Grover SBS, Kumar S, Bhansali A, Jaggi S. Psychological impact of type-1 diabetes mellitus on parents: an exploratory study from North India. Int J Diab Dev Ctries. 2011;31:174-9.

38. Abdel-Rahim A, Lachine N, Zeitoun M, El-Gendi W. Intensified insulin therapy during fasting of Ramadan type 1 diabetic patients. Int J Diab Dev Ctries. 2011;31:216-22.

39. Alsafar H, Jama-Alol KA, Hassoun AAK, Tay GK. The prevalence of type 2 diabetes mellitus in the United Arab Emirates family registry. Int J Diab Dev Ctries. 2012;32:2532.

40. Bener A, Yousafzai MT, Al-Hamaq AO. Familial aggregation of T2DM among Arab diabetic population. Int J Diab Dev Ctries. 2012;32:90-2.

41. Nagarathna R, Usharani MR, Rao AR, Chaku R, Kulkarni R, Nagendra HR. Efficacy of yoga-based lifestyle modification program on medication score and lipid profile in type 2 diabetes - a randomized control study. Int J Diab Dev Ctries. 2012;32:90-2. 